\title{
ANDANZAS DEL PADRE MALDONADO Y SU PRIVADO EJEMPLAR
}

Tras la privanza de Lerma, muerto ya el tercer Felipe, bien sabían los españoles a qué atenerse cuando con el nuevo rey subió la estrella de Olivares. No tardará Quevedo en empezar su Politica de Dios, dirigida al todopoderoso conde, con la abierta intención, apuntaba Raimundo Lida, de retratar al "perfecto valido". Los halagos resultaban inevitables. Pocos años después se compone una pieza teatral, Cómo ha de ser el privado, que para su editor, Miguel Artigas, era de Quevedo. "Franca muestra de adulación cortesana -escribe Lida- rápidamente traducida a comedia por una pluma inhábil para el teatro serio"'. Así insinuó la sospecha, luego confirmada, de que esa pluma no fuese la de don Francisco: "hube de señalar", recordó más tarde, "la ausencia de toda dramática energía y lo flojo e insípido de los personajes y sus discursos"'2. Ambas obras, méritos aparte, figuran en la copiosísima serie de textos políticos, entre lisonjeros y morales, que florecieron a la sombra de Olivares. Claro está que hubo antecedentes, no siempre recordados, escritos cuando el duque de Lerma se hallaba en su apogeo. Uno de ellos merece aquí atención.

Hace mucho sentí curiosidad por un tratadillo inédito cuyo tema y título, El perfecto privado, invita a cotejarlo con escritos posteriores. Casi nadie lo tiene en cuenta ${ }^{3}$. Según la portada es obra

1 Véase Raimundo Lida, "Cómo ha de ser el privado: de la comedia de Quevedo a su Politica de Dios", Letras Hispánicas, México, 1958, pp. 149 ss. Aunque no entra a discutir la atribución, sus reservas se advierten no sólo en esas palabras, sino también en observaciones literarias: "teatro pasivo, de figuras de palo y de discursos igualmente inertes" (p. 152). Ese artículo a pareció primero en Libro jubilar de Alfonso Reyes, México, 1956, pp. 294-308.

2 "Sobre el arte verbal del Buscón", PhQ, 51 (1972), p. 261, nota 20; apunta allí que una carta de Amédée Mas, comentando las deficiencias señaladas en 1956, puso "muy en duda" la atribución.

3 Cf. Tomás Valiente, Los validos en la monarquía española del siglo xüii, Madrid, 1965, pp. 116 ss. 
de un fray Pedro Maldonado, agustino, a quien muy pocos mencionan: sólo a propósito del poeta Medrano y también de Garcilaso Inca. Puede que el opúsculo de Maldonado tuviera alguna difusión, pues al menos se conservan cuatro copias antiguas ${ }^{4}$. En la dedicatoria el autor se dirige a Lerma, a quien conoce, y alude al fallecimiento de la duquesa doña Catalina, 1603. Ya se sabe que la muerte de esa dama fue afortunado asunto literario y Quevedo la llora en el soneto "Si con los mismos ojos que leyeres"'. Esto invita a situar el opúsculo por ese año. Quevedo y Maldonado anduvieron entonces en la corte vallisoletana; Maldonado con brevisima y grande fortuna, seguida de vertiginoso derrumbe. Ignora que tuviesen relación y no consta que don Francisco leyese algún traslado de ese manuscrito carente de vuelo, aunque decorosamente compuesto. Hoy ante todo interesa por su fecha. Si textos como el del padre Guevara corresponden a tiempos en que la privanza tenía límites, esta obrilla se liga a la aparición del valimiento absoluto, triste momento clave. De otro lado ocurre que la novelesca personalidad del autor tiene atractivo y merece conocerse. Por lo pronto surge inesperada cuestión previa: la vieja atribución del Perfecto privado a fray Pedro Maldonado, agustino, mueve tantas dudas como las que provocó Artigas al adjudicarle a Quevedo esa comedia.

Aunque cabe esclarecer el punto no alcanzaré a estudiar el tratadillo y menos a compararlo con la Política de Dios; más bien entrarán en escena ciertos respetados autores: Francisco de $\mathrm{Me}$ drano, Garcilaso Inca, el cronista mestizo Blas Valera, el venerable Luis de la Puente y aun el ascético jesuíta Alonso Rodríguez. Vaya lo uno por lo otro.

* Hay un Tratado del perfecto pribado, al que adelante me refiero, Bi blioteca Nacional de Madrid, ms. 18335; dos se llaman Discurso del perfecto privado, en la misma sección, ms. 6778 y 18721, núm. 48. Existe además una pobre copia en la Academia de la Historia, Col. Salazar, ya citada por Gallardo, la cual equivoca el nombre y llama al autor Juan, como el gran biblista (cf. Gregorio de Santiago Vela, Ensayo de una biblioteca ibero-americana de la Orden de San Agustin..., basada en el catálogo... del P. Bonifacio Moral, Madrid, voi. V, 1920, pp. 85-91).

5 Inscripción en el túmulo de la duquesa; cf. Quevedo, Obras completas, ed. de José Manuel Blecua, t. 1, Poesia original, Barcelona, 1963, p. 289. Doña Catalina de la Cerda, hermana del duque de Medinaceli, mereció particularísimo afecto y gratitud de Quevedo. Góngora escribió entonces su bellísimo "AAyer deidad humana, hoy poca tierra!" (ROBERT JAMMEs, Etudes sur l'œuvre poétique de Don Luis de Góngora y Argote, Bordeaux, 1967, p. 268). Ya se sabe que Góngora y Quevedo vivían - y reñían- en Valladolid por esos tiempos. 


\section{EL ManUscrito Y sUs Circunstancias}

El texto que se tiene por mejor es una copia algo tardía, aunque de época:

Tratado / del perfecto pribado. / Autor / El R.do P. M. F. Pedro / Maldonado de la Orden / de S. Agustin Califica- / dor del Santo Oficio / de la Ynquisicion. / Al Ex. ${ }^{\text {mo }}$ S.r D. Francisco de / Rojas y Sandoval Marq. ${ }^{\text {s }}$ de De- / nia y Duque de Lerma Su/ miller de Corps, Cavalleri- / ço de su Mag. ${ }^{d}$ de sus Cố- / sejos de Estado y Guer- / ra, y Capp. ${ }^{\tan }$ Gen.' de / la Cavalleria / de España.

Ms. 18335 de la Biblioteca Nacional de Madrid. Sello de Pascual de Gayangos. En 4, 2 hojas s. n. + 35 hojas nums. En la misma sección, el ms. 6778 ofrece igual texto según Santiago Vela, lo cual sólo he verificado en rápido cotejo; difiere en el título, Discurso del Perfecto Privado; además presenta a Maldonado como "Confesor del Duque de Lerma", noticia extraña. Hay otras dos copias en Madrid. Aparte estas cuatro, se conoce otra por referencias: al parecer es más antigua y original; Nicolás Antonio cuenta haber recibido unos Avisos del privado, inéditos, de Pedro Maldonado, sin año ni lugar, dirigidos al duque de Lerma ${ }^{6}$. Se ignora su paradero.

Ya empezarán aquí las confusiones a que nos lleva este personaje, algunos de cuyos lances llegan, como se verá, al delirio. No sólo hay diferencias en el título, sino que se carece de fecha. Las portadas de las copias hablan de un fraile entonces famoso; falta averiguar si lo era cuando la obrilla se escribió. En general, los repertorios biobibliográficos saben que Pedro Maldonado entró a la Compañía siendo muchacho y que luego se hizo agustino, pero ignoran cuándo7. E1 historiador jesuita Antonio Astrain nos presenta a un Pedro Maldonado, joven e inquieto, cuyas desventuras lo mueven a alborotar la Corte justamente entre 1603 y 1604; tuvo y perdió el favor del duque, y acabó en estrepitosa caída. Astrain no conoce el Tratado ni advierte que el mozo pasó luego a San

6 Bibliotheca hispana nova, Madrid, 1962, p. 211. El gran bibliógrafo alcanzó a un sobrino de Maldonado, José, quien le dio los Avisos; este José tuvo a su cuidado la impresión de la obra póstuma de fray Pedro Libro espiritual, que sirve para la lección y meditación, Sevilla, 1631; todas las referencias posteriores que conozco provienen de Nicolás Antonio.

7 Desde Antonio, quien erradamente afirma que fray Pedro murió a los 38, hasta Santiago Vela (cf. infra, nota 18). 
Agustín $^{8}$. Esto confirma la presunción de que el original debió componerse hacia 1603, cuando Maldonado tenía la confianza de Lerma; sin embargo, entonces y aun después era todavía jesuíta. Por su parte, el agustino Santiago Vela careció de las noticias de Astrain y fiándose en exceso de los datos que consignan las portadas, pensó que el Perfecto privado fuese posterior a 1610 , cuando "se graduó de maestro". Acepta que fuese "Calificador del Santo Oficio", y aún más, confesor del duque. Esto último lo desconcierta y le provoca justificadas dudas:

...nos llama en verdad la atención, porque si en realidad ejerció el empleo de Confesor de aquel magnate, trasladaría su residencia a Madrid y acaso en este punto moriría, y de ninguno de estos dos extremos hemos encontrado el menor vestigio en la documentación de nuestras casas de Madrid. Esto nos hace dudar algo de la existencia del título discutido, quedándonos el recurso de decir... que es una atribución indebida del copista, pues... nadie puede asegurar que tal título le escribiera el mismo autor'.

Ninguno llega a ver en su punto este tratadillo. El Privado debería entenderse como parte de las relaciones entre el amo de España y un joven jesuita, brillante y ambicioso, cuya fortuna iba creciendo. Nadie sabe cómo logró entrar en la Corte; tengo para mí que lo favoreció su fama en el púlpito, llamado a predicar en diversas ciudades. Sobre sus relaciones con Lerma, la breve dedicatoria da referencias. Quiso el autor, dice, gastar “algún estudio en sacar de la Escritura" y autores santos ideas para "la salvación de Vuestra Excelencia" y aun para "su mayor perfección". Ardiendo en "entrañable deseo" había emprendido el trabajo "antes de conocerle", y el fuego aumentó con "los soplos de tantas mercedes como me ha hecho"; y añade: "Lea este papel no como mío, que ni por los años ni por la experiencia le puedo dar autoridad". Nada indica que fuera confesor del duque; quizá una lectura apresurada o alguna noticia fabulosa movió a un tardío copista a darle ese rango. Maldonado le sugiere al valido que "algunas noches deste ibierno (pues la costumbre le obliga a alguno, y la viudez a mayor recogimiento) lea este papel". Rezan así palabras del úl-

8 Cf. Antono Astrarn, Historia de la Compañia de Jesús en la Asitencia de España, Madrid, 1909, vol. III, lib. II, cap. 20. Esta obra fundamental sólo atiende de paso a Maldonado; la atención aquí se dirige al rebelde Men. doza. Ya Dámaso Alonso advirtió que el joven jesuita reapareció luego como agustino (cf. infra, nota 11).

9 op. cit., p. 86. Debo adelantar que el Privado esconde incógnitas que sólo cabe considerar páginas adelante. La fecha propuesta es razonable, el autor no lo fue. 
timo párrafo de la dedicatoria, concluido ya el opúsculo, hacia diciembre de 1603. Hasta donde hoy sé, esto resulta lo más lógico.

No faltarán subidas lisonjas. Duda enviarle el texto, dice, "así porque estando Vuestra Excelencia vivo no es necesario el Perfecto privado escrito, como porque quizá alguien... me tendría por insigne adulador, viendo escritas por propiedades del perfecto privado las virtudes de Vuestra Excelencia". Quisiera que Lerma llegase al grado de ejemplar máximo, espejo de validos. "Y si este deseo merece alguna recompensa", sea la de leer esas páginas.

Según todo ello, el texto debe pertenecer al jesuita de que habla Astrain; no se imprimió, claro está, por el fracaso del autor en la corte; y si Pedro Maldonado no figura en los repertorios de escritores de la Compañía, de Rivadeneira para acá, fue porque todos sus libros aparecieron cuando ya era agustino.

Por entonces se vivían tiempos particularmente agitados. Subsistía, aunque ya menguada, vieja desazón entre los jesuítas hispanos, y es posible que restos de ello retoñaran en Valladolid, como piensa Dámaso Alonso. Con todo, la gran tormenta había pasado ya, y desde mucho. Escribe Astrain:

Aunque las turbaciones que agitaron a la Compañía... a principios del siglo Xvir pueden llamarse continuación de las que se levantaron en tiempos de Felipe II, ... tienen un carácter muy diverso, ya se atienda a los designios de los agitadores, ya a los medios que pusieron en juego' ${ }^{10}$.

Entre los inconformes los hubo muy distintos: religiosos de vida relajada que se defendían enredando; descontentos con la regla; otros opuestos al poder de la curia romana -en manos extranjeras-, siendo la Compañía eminentemente española. La verdadera crisis se produjo cuando hacia 1586 cundieron los memorialistas, quienes se dirigían a la Corte o al Santo Oficio buscando apoyo. La inquietud ganó de diversos modos a varones tan ilustres como Juan de Mariana o José de Acosta. Los intentos de este último, a quien ayudaba Felipe II para limitar el poder del padre general Claudio Aquaviva, fracasaron cuando se reunió en Roma en 1593 la congregación general de la Compañía. A principios de 1594 la batalla quedó resuelta y el bando de Acosta derrotado ${ }^{11}$. El sabio naturalista, historiador y teólogo murió en 1600, decaído en la

I0 Con estas palabras se inicia el cap. 20, encuadrándolo.

11 Astrain, loe. cit.; León Lopetegui, El P. José de Acosta, S. I., y las misiones, Madrid, 1942; Miguel de a Pinta Llorente, O. S. A., Actividades diplomáticas del P. José de Acosta, Madrid, 1952. Importan aquí los comentarios a Astrain de Dámaso Alonso, Vida y obra de Medrano, Madrid, 1948, vol. I, caps. iii y iv. 
orden, pero Francisco de Medrano, siendo aún jesuita, no temió dedicarle un poema. Lo recuerda intencionadamente Dámaso Alonso, y también que el mismo Medrano le dirigió una oda a Pedro Maldonado, su antiguo compañero. Como se verá, los líos de Maldonado no muestran relación visible con la rebeldía de diez o veinte años atrás. Se enfrentó, en cambio, a los manejos del padre Mendoza, gran agitador y nada observante como religioso, hasta desesperar a sus superiores. Este jesuita Fernando de Mendoza ganó sorprendente poder en Nápoles, como confesor de la condesa de Lemos, hermana de Lerma. Logró a la vez el apoyo papal y el de la corte española, y se enfrentó con éxito al propio Aquaviva. Vuelto de Italia el díscolo en 1603, no tardó en tener desavenencias con un importantísimo miembro de la orden, el padre Ricardo Haller, confesor de la reina. Era natural que Mendoza riñese también con Maldonado, favorito entonces de Lerma y por ello rival a quien convenía eliminar.

Fue un laberinto de intrigas en el más alto nivel. La lucha ardía y hubo superiores en Valladolid que, como el padre Villegas, prefirieron hurtar el cuerpo entrando a ejercicios espirituales ${ }^{12}$. Participaron el propio duque y con él Su Majestad; la condesa de Lemos, acabada de enviudar del virrey de Nápoles, y amiga de Clemente VIII, quien continuamente intervino en su favor; el cardenal Ginnasio, nuncio ante la Corte de Valladolid; el padre Aquaviva, general de la Compañia, puesto en los peores apuros, y los cuatro provinciales jesuítas de España. Ante esas figuras, el mo. zalbete Maldonado contaba poquísimo. Para su mal tuvo importancia momentánea, no siendo sino un comparsa, y pudo acabar en chivo expiatorio. En la Compañía, no hay duda, fueron indulgentes con él, y aun lo salvaron cuando peor le iba. Todo este episodio no puede narrarse con entera certeza, pues hay lagunas en la documentación; la que manejo es incompleta ${ }^{13}$, aunque bas-

12 Léase el reproche que el padre general Aquaviva le hace a Joseph de Villegas, prepósito de la Profesa y superior inmediato de Maldonado: "Hame parecido mal que en tiempo de semejantes ruidos y quiebras V. $R$. se haya retirado a la riberilla con título de hacer los ejercicios espirituales" (carta de Roma, 23 de agosto de 1604; Arch. Rom. S. 1., Castel., 7, 1, Epist. Gen., 1603-1606, fol. 77v). Por Astrain se sabe que luego fue nombrado prepósito el P. Hernando de la Cerda, a quien de inmediato atacó el bando de Mendoza con tal fiereza que prácticamente no ejerció el cargo. El P. Hernando fue perseguido junto con Maldonado.

13 Astrain lamenta la pérdida de la correspondencia de Castilla enviada al padre Aquaviva; en parte se reconstruye por las respuestas de Roma, que conozco. No he logrado ver todas las cartas del nuncio Ginnasio al Vaticano, pero sí una fundamental; tampoco he revisado la relación del padre Ricardo Haller, muy usada por Astrain. Gracias a la generosidad del padre Miguel 
tante para esclarecer el conjunto. El ordenamiento de aquellos desencadenados sucesos resulta difícil y. el padre Astrain no logra seguir una línea cronológica clara. Hay además complicaciones inesperadas.

Hubo dos Pedro Maldonado, ambos jesuítas y casi de la misma edad, que para colmo coincidieron en Valladolid durante estos agitados tiempos. Se trata de uno de esos casos de homonimia en que abundan las letras hispánicas; aun así, es de los más curiosos. Tenían apenas cinco años de diferencia. Uno, de la Provincia Castellana, vivía en el colegio de San Ambrosio, 1603, mientras el otro, venido de la Bética, residía en la Casa Profesa de la misma ciudad. En ello nadie había reparado y ha habido confusiones. El distinguirlos más de la cuenta me llevó a error, pues creí que uno fuera el autor del Tratado y otro el andaluz que se hizo agustino y publicó varios libros. No hay tal. Consta que el sevillano Maldonado, compañero de estudios de Medrano, eventual amigo de Garcilaso Inca, fue el osado mozo que alcanzó el aprecio de Lerma y que, tras caer en desgracia, salió de la orden y compuso obras espirituales y escriturarias, amén del Privado.

Será preciso conocer y descartar al homónimo. Luego podrá reseñarse la vida, rica en incidentes, de nuestro autor.

\section{El otro Pedro Maldonado}

Hacia 1578 o principios de 1579 nació en Segovia el Pedro Maldonado castellano. Se conocen sus rastros al menos hasta 1614 , en el colegio de León, donde residió buen tiempo. En ese mismo año murió el nuestro, vuelto a la patria andaluza. Parece que el homónimo tuvo familiares en la Compañía, pues en el colegio de Salamanca se hallaba en 1606 el padre Paulo Maldonado, también segoviano, de cincuenta y tres años de edad y veintisiete de jesuíta.

En el catálogo trienal de 1603 aparece en el colegio de Valladolid el hermano Pedro Maldonado, "natural de Segovia, patria y obispado". Lleva el núm. 22, alumno de $3^{\circ}$ de teología; tiene veinticinco años y nueve en la orden. Andaba próximo a ordenarse y no se hallaba en situación de tratar con el duque. Gracias a los

Batllori, S. I., y asimismo del P. Antonio de Egaña, S. I., trabajé varias semanas en 1966 y 1967 en los archivos jesuíticos de Roma; conocí bastante de la ignorada mocedad de Maldonado y de sus años finales en la Compañía, aunque no alcancé a completar el conjunto; ya antes había obtenido noticias sobre el autor en el Archivo de la Provincia de Toledo, Alcalá de Henares, por gentileza del P. Francisco Mateos, S. I.; con ello, más los ms. del Privado, y las olvidadas obras de Maldonado, cabe mejorar notoriamente el conocimiento del caso. Agradezco a mi antiguo alumno el Dr. José Anadón su ayuda para verificar noticias colacionadas por Astrain, existentes en Roma. 
varios catálogos consultados pueden establecerse con mucha aproximación sus hitos biográficos ${ }^{14}$. Entró a la Compañía aún adolescente, el 20 de abril de 1594. Tras el noviciado y primeros estudios completó tres años de artes y en abril de 1603 sólo le faltaba un año de teología. Luego lo encontraremos ya ordenado en León, 1606, con el núm. 5, a sus veintisiete años. Lo ocuparon en leer latín, tarea modesta.

Una noticia de Astrain, quizá equivocada, debe consignarse. Cuando el sevillano anduvo procesado, lo recluyeron en el colegio de León, allí se perdieron sus huellas. ¿Nueva coincidencia o es que Astrain lo confundió con el segoviano? Lo ignoro. Por lo demás las noticias de éste no se esfumaron. En 1607, cierto, ya no está en ese colegio y se lee la curiosa indicación: "Ninguno ha sido despedido"; más bien lo hallaremos en Palencia, núm. 5, como predicador. Llegados a 1611 lo tenemos de vuelta en el colegio de León, con el núm. 7, a los treinta y tres, gozando de buena salud. Se da entonces la fecha de su ingreso a la orden y hay útiles noticias sobre sus actividades: enseñó latín un año, otro casos de conciencia y después se le dedicó al púlpito. No olvidemos que el andaluz fue famoso orador sagrado: hasta en esto coincidieron. Todo indica que en esta etapa el Maldonado segoviano tuvo el aprecio de sus superiores.

Justamente por entonces, el 4 de junio de 1612 le escribe desde Valladolid el padre Luis de la Puente una carta sagaz, digna de su alto espíritu, la cual se entiende mejor al saber que su destinatario en León no era el Pedro Maldonado sevillano. El padre Camilo María Abad, S. I., biógrafo del venerable Puente, duda de que carta tan reconfortante pudiera dirigirse al atolondrado sujeto que pinta Astrain (y que según éste pasó castigado a León). Aun así, Abad reconoce que ciertos rasgos del carácter de Maldonado (el otro, el sevillano) corresponden a los consejos de Puente $e^{15}$ El famoso ascético, varón respetadísimo, rector anteriormente del Colegio de San Ambrosio en Valladolid, prueba hondo conocimiento de su corresponsal, a quien exhorta:

14 Me baso en los catálogos trienales del ARSI, Castellana, 15, I, Valladolid, Colegio, 1603; León, 1606; Salamanca, 1606; Palencia, 1609; León, 1611 y 1614; también en las copias existentes en Alcalá.

15 Luis de la Puente, Obras escogidas, Bib. Auts. Esps., introd. de Camilo María Abad, S. I., Madrid, 1958, p. xii. El venerable Puente fue rector del colegio de Valladolid entre 1594 y 1596, y luego volvió a serlo; enseñó teología y casos de conciencia; seguramente fue maestro del segoviano. Para la carta de Puente, pp. 391 s. Al parecer, este Maldonado trataba a la condesa de Treviño. Marcel Bataillon señala la importancia de las "grandes obras" de Puente (Erasmo y España, trad, de A. Alatorre, México, 1966, p. 752) 
Vuestra Reverencia debría fundar su perfeción y ordenar su oración a fundarse en una profunda humildad para con Dios y para con los hombres, reconociendo que sin Dios nada puede ni vale; y procurando el más bajo lugar entre los hombres, aborreciendo el apetito de ser loado o estimado de ellos. Con esta humildad junte una grande confianza en la divina omnipotencia para acometer cualquier impresa del divino servicio.

Puente nos revela el mal e insiste:

...Y crea Vuestra Reverencia que, si tiene celo de homar a Dios, Dios le tendrá de honrar a Vuestra Reverencia con la verdadera honra que vale para la vida eterna.

Éste, pues, fue el Maldonado segoviano. Todavía en 1614 lo hallaremos, distinguido por los suyos, en el mismo León. Sus fuerzas son sólo medianas y continúa predicando. Aunque todo cabe, sería una sorpresa el que este homónimo hubiese participado en aquellos disturbios de la Corte.

\section{Pedro Maldonado, autor sevillano}

El Inca Garcilaso llama "Pedro Maldonado de Saavedra"'16, a nuestro autor, jesuita sevillano que leía Escritura en Santa Catalina de Córdoba en 1600. El doble apellido lo usaba su padre, aunque no, que sepamos, el hijo. Nació éste en 1573 o quizás en 1574 (le llevaba unos cinco años al segoviano). Tiempo adelante, nuestro inquieto andaluz tomó hábitos de agustino, lo cual quedó resuelto al terminar 1605 y se ejecutó al principiar 1606. El cambio de orden, no la fecha, fue bien conocida entonces y así lo apuntaba ya Nicolás Antonio ${ }^{17}$. Fray Pedro tuvo renombre como autor y sobre todo en el púlpito. Murió en 1614 en su ciudad natal, cuando tenía cuarenta y un años, o quizá meses menos. Algunos, por error, dicen que falleció a los treinta y ocho.

Pues bien: Pedro Maldonado figuró muy pronto entre las glo-

It Comentarios reales, Lisboa, 1609, lib. I, cap. 6; el Inca, ducho genealogista, conocía el entronque con los Saavedra. Es extraño que ningún biógrafo de Garcilaso, desde Riva-Agüero hasta hoy, advierta que Maldonado fue luego autor relativamente fecundo; nadie da noticia de la personalidad de este curiosísimo sevillano: ni aun los más recientes, como JoHN G. VARNER, El Inca. The life and times of Garcilaso de la Vega, Austin and London, 1968, y Aurelio Miró Quesada S,, El Inca Garcilaso y otros estudios garcilasistas, Madrid, 1971; tampoco indican que se hizo agustino.

17 Cf. supra, nota 6 . No se olvide que Antonio conoció a don Josef Maldonado Dávila, sobrino de nuestro autor. 
rias hispalenses, y por cuenta propia: en ello nada contaron su amistad con Medrano ni sus relaciones con figuras hoy ilustres. Pacheco guardó un lugar para su retrato, que no sé si llegó a ejecutar; Rodrigo Caro lo nombra y tanto Nicolás Antonio como Ortiz de Zúñiga recogen noticias de su vida. A ellos les seguirán Díaz de Valderrama (Arana de Valflora), Matute, Bejarano y otros. Se ha dicho que nació en 1576 , pero un cotejo de los catálogos trienales retrasa la fecha dos o tres años. Fueron sus padres distinguidos y ricos: el caballero de Santiago don Melchor Maldonado de Saavedra y doña María -o María Ana- de la Barrera; no resulta fácil llevar la cuenta, pero ocho o nueve hijos de don Melchor Maldonado, coronel en las Alpujarras, fueron religiosos. Cinco, entre frailes y monjas, tomaron hábito agustino, a los cuales se unió tardíamente Pedro; Blas Maldonado, jesuita, no creo cambiara de orden; de otro hermano sabemos que fue "seglar": Melchor Maldonado de Saavedra (padre de Josef Maldonado Dávila, a quien trató Nicolás Antonio). De los mayores, la madre Elvira fue abadesa de varios conventos, y fray Juan de la Barrera, quien profesó como agustino en 1575, llegó a prior en Salamanca; se afirma que murió santamente. Otro de los frailes se llamó Fernando de Saavedra ${ }^{18}$.

Aún niño, a los trece o menos, Pedro se hizo jesuíta; ya estaba en la Compañía su hermano Blas. En una lista adjunta al catálogo trienal de San Hermenegildo de Sevilla, 1587, entre "los que en este tiempo han sido recebidos en el Colegio" figura a la cabeza

18 Santiago Vela, loe. cit. El nombre de la madre, doña María, lo da Nicolás Antonio. Ya se sabe que el Libro de retratos de Pacheco quedó incompleto; también dejó lagunas Rodrigo Caro, Varones insignes en letras naturales de la ilustrisima ciudad de Sevilla, con adiciones y prólogo de Diego Ignacio de Góngora, ed. de Santiago Montoto, Sevilla, 1915; cf. p. 72; Diego Ortiz de Zúñiga, Anales eclesiásticos y seculares de la muy noble y muy leal ciudad de Sevilla, Madrid, 1677, p. 591; Mario Méndez Bejarano, Diccionario de escritores, maestros y oradores naturales de Sevilla y su actual provincia, vol. II, parte I, Sevilla, 1923, p. 7. El coronel don Melchor, según veremos, casó dos veces, pienso que con dos hermanas. La primera mujer fue doña Ana de la Barrera (cabe también que fuera María Ana). Ortiz de Zúñiga admira que don Melchor tuviese en doña Ana siete hijos, todos religiosos "cosa que no sucede vulgarmente"; pero hubo más hermanos, y un hijo del primer matrimonio fue don Melchor Maldonado de Saavedra, veinticuatro de Sevilla y procurador mayor en la Corte, y desde 1604 juez de la Contratación en Sevilla (cf. Justino Matute y Gaviria, Hijos de Sevilla, Sevilla, 1887, vol. II, p. 195). El propio fray Pedro, según lo advierte Santiago Vela, informa que en 1606 había ocho o nueve en la iglesia, seis de ellos agustinos; las noticias hablan de tres monjas. La correspondencia jesuítica nombra a su hermano Blas, de la Compañia, y a otro "seglar", Melchor probablemente (infra, notas 28 a 30 ). 
Medrano y con el núm. 12 Pedro Maldonado, unos tres años menor que el poeta ${ }^{19}$. Todos probablemente debieron pasar al noviciado de Montilla. La amistad con Medrano pudo nacer entonces, si es que no fuera antes, en su patria. Por muchísimo tiempo la figura central de la casa montillana fue el famoso autor ascético Alonso Rodríguez, rector entonces, según catálogos de 1585 y 1587. Cabe así afirmar que tan insigne varón tuvo a su cargo a Francisco de Medrano: otra cosa fue que éste no perseverara. Gil González Dávila, también importante autor espiritual ${ }^{20}$, se hallaba a la cabeza de la Provincia Bética. En carta al padre general Aquaviva escribe González Dávila:

Montilla es casa de santidad y de todo buen ejemplo, llena de consuelo y alegría y de verdadera institución de la Compañía y trato en los novicios. Redunda de ella grande edificación a toda la Provincia, y grande utilidad, porque los que salen de allá se vee que proceden con espíritu de religión, de obediencia y abnegación, señalándose en esto. $Y$ no veo cosa en que $V$. $P$. haya hecho mayor regalo a esta Provincia, ni remedio más a la raíz, que habernos traído allá el $\mathrm{P}$. Alonso Rodríguez, y espero que pasando por sus manos los de la $3^{a}$ probación, como se procura y procurará, será el fruto más de estima, y se veen ya prendas de esto21.

El padre Rodríguez fue allí maestro de novicios por decenios y, al pasar a rector, aun cuando debiera atender a los de la última

I9 ARSI, Baetica, Cat. trien., Sevilla, colegio, 1587; lista general de 1590; Sevilla, colegio, 1593; Málaga, 1597; Córdoba, 1599 y 1602; Cast., Valladolid, profesa, 1602 (en listas de 1603). En el Arch. de Alcalá, ya citado, Cazorla, 1606. La fecha más probable de nacimiento resulta 1574, o quizá fines de 1573. Para referencias a otros jesuitas de la provincia andaluza me remito a los catálogos de 1574 a 1606 .

20 Durante las andanzas de Acosta frente a Aquaviva, González Dávila estuvo con el general (PInTA Llorente, op. cit., passim). Sobre Alonso Rodríguez y González Dávila, cf. Miguel Nicolau, "Espiritualidad de la Compañia de Jesús en la España del siglo xvi", y particularmente Camilo María ABaD, "Gil González Dávila, S. J. Sus pláticas sobre la regla de la Compañía de Jesús"; ambos artículos en el vol. ed. por la Universidad Pontificia de Salamanca, Corrientes espirituales en la España del siglo xvi. Trabajos del II Congreso de Espiritualidad, Barcelona, 1963, pp. 341-361 y 362-391. Claro está que por la provincia Bética desfilaron o residieron muchos jesuitas de importancia que no consignamos, como Francisco Arias, Antonio Cordeses y otros. Bataillon presenta a Luis de la Puente y Alonso Rodríguez como los autores en quienes vuelven a florecer las viejas corrientes de la espiritualidad jesuita; al referirse a ellos recuerda el pensamiento del maestro Ávila y el del padre Granada (op. cit., pp. 752 ss.).

21 Astrain, op. cit., vol. III, apéndice 5. Dámaso Alonso reproduce parte de este pasaje. 
probación -ya en el momento del sacerdocio-, mantenía directa jurisdicción sobre todos los sujetos de la casa.

No cabe olvidar, en fin, que el recuerdo del maestro Juan de Ávila, muerto en Montilla años atrás y enterrado en el noviciado, continuaba influyendo poderosamente ${ }^{22}$. Vivió en esa casa el doctor Juan de Vergara, quien lo había alcanzado; allí habían residido varios discípulos de Ávila, así como otros jesuítas que atestiguaron en la causa de beatificación, o que escribieron sobre él, como el padre Martín de Roa o el lego Sebastián de Escabias ${ }^{23}$. Montilla era cabeza de los estados de los marqueses de Priego, protectores de la Compañía y del beato Ávila, y en aquella corte campesina pasó más de un cuarto de siglo el Inca Garcilaso, antes de trasladarse a Córdoba. Por entonces las obras de Ávila tenían amplia difusión y su biografía la había escrito fray Luis de Granada. La espiritualidad de la Contrarreforma andaluza se mantenía con vigor. La Compañía, a la vez que se hallaba en apogeo, sufría en España la grave crisis que se desató en los memorialistas.

Vale la pena considerar el marco de la mocedad de Maldonado y Medrano. La Provincia Bética contaba a fines del Xvi con espléndidos maestros. Por ejemplo el teólogo Tomás Sánchez; los escriturarios Jerónimo de Prado, Juan de Pineda, Luis del Alcázar y Juan Bautista de Villalpando; el historiador y autor espiritual Martín de Roa, quien a veces leyó retórica; pero el retórico por excelencia fue allí Melchor de la $\mathrm{Cerda}^{24}$, que residía en Sevilla

22 El doctor Vergara, quien fue confesor de la "santa marquesa de Priego", protectora de Ávila, residía aún en la casa montillana en 1574; fue natural de Sanlúcar. En su leidísimo Ejercicio de perfección y irtudes cristianas, Alonso Rodríguez cita a cada momento a Juan de Ávila (sólo en el lib. I dos docenas de veces); señala su relación con Ignacio de Loyola y prácticamente lo siente como jesuita; Ávila, advierte Rodríguez, instruyó a varios jóvenes que entraban a la Compañía (lib. III, trat. I, cap. 3). Acude más a Juan de Ávila que a jesuítas como Puente, Nadal, Suárez, Tomás Sánchez o Francisco Arias. En una ocasión anota: "Acuérdome que decía un padre muy grave, que había sido mucho tiempo superior en la Compañía..."; una apostilla aclara que era Antonio Aráoz (lib. III, trat. V, cap. 6); Aráoz tuvo relación directa con Ávila (cf. JUAN DE Ávila, Obras completas, ed. e introd. de Luis Sala Balust, Madrid, 1952, vol. I, passim). Sala Balust compara el Ejercicio con el espíritu de Ávila (op. cit., vol. II, 1953, p. 11). Para el doctor Vergara, vol. I, p. 179; hay más referencias de ello.

23 El P. Martín de Roa fue el biógrafo de dos discípulos de Árila, doña Sancha Carrillo y la "santa condesa" de Feria. También tuvieron relación con el beato el padre Diego de Guzmán y el hermano Escabias, autor éste de los Casos notables de la ciudad de Córdoba (ed. de A. González Palencia, Madrid, 1949); la paternidad de este texto anónimo la resolvió Lurs Sala Balust, "El H. Sebastián de Escabias, S. L", $M H, 1979$, núm. 10, 266-296. 24 Las obras de estos jesuitas se describen en conocidos repertorios como 
en 1587; pienso que Cerda influyó en Francisco de Castro, famoso al principiar el xvn; por cierto que Castro sólo le llevaba cuatro años a Medrano. La actividad intelectual y el gusto por letras humanas y divinas tuvo en los jesuitas andaluces de entonces una etapa floreciente. Nada faltaba para que Medrano se cultivara en la mejor latinidad, ni para que Maldonado se convirtiera en escriturario: lo fue, aunque sin acercarse al gran biblista jesuita de años atrás, Juan Maldonado, al parecer pariente suyo muy pró$\operatorname{ximo}^{25}$.

En la lista general de la Bética, mayo de 1590, encontramos al hermano Pedro en el colegio sevillano de San Hermenegildo, con el núm. 257. Tiene dieciséis años y cuatro en la orden. El padre Alcázar, comentarista del Apocalipsis y el retórico Cerda enseñaban allí en 1591, mientras Jerónimo de Prado residía en la Profesa sevillana, ocupado en comentar a Ezequiel. A fines de abril de 1593 Pedro sigue estudios en el mismo colegio, núm. 37 de la casa; a los diecinueve tiene buena salud y lleva cursados tres años de artes y uno de iteología; sigue como maestro allí Luis del Alcázar, famoso biblista. Con el hermano Pedro acaban de ocurrir dificultades subidas de punto, aunque el escándalo, para bien del estudiante, amagó más que estalló. Quizás más que culpas reales pudo haber fantasías calenturientas. Desde Sevilla, en carta al general de la orden Aquaviva, el padre Melchor de Castro expone lo ocurrido y pide la dimisión, a juzgar por la sumilla ${ }^{26}$. Tras hablar de otro sujeto que también se hallaba en graves dificultades, Melchor de Castro escribe el 14 de junio de 1593:

el de Sömmervögel o el de Uriarte y Lecina. Noticias de los autores en Astrain, op. cit., vols. III y IV. Aprovecho aquí los catálogos trienales béticos. Melchor de la Cerda ha dejado al menos cinco volúmenes de asuntos teóricos latinos (Sevilla, 1598; Lyon, 1614). Famoso maestro, leyó retórica en varios colegios andaluces por muchísimos años. También la enseñó un tiempo Martín de Roa, quien junto con los biblistas Jerónimo de Prado y Juan Bautista de Villalpando, celebradísimos, se hallaban en Córdoba en 1587, cuando estudiaba allí el poeta Medrano.

25 Juan Maldonado fue extremeño, al parecer de Casas de la Reina (C. Sömmervögel, Bib. de la Compagnie de Jésus, Bruxelles-Paris, 1894, V, col. 403). Según noticias de Argote de Molina y de Ortiz de Zúñiga, Juan, el gran escriturario, fue sevillano por sus padres, e hijo natural del coronel don Melchor Maldonado, en la mocedad de éste. En tal caso sería hermano paterno de Pedro (cf. Justino Matute, op. cit., pp. 39-41; id., Adiciones y correcciones a los "Hijos de Sevilla"... de D. Fermín Arana de Valflora, Sevilla, 1886, p. 101). Por ser Melchor nombre recurrente en la familia y mediar muchos años entre los supuestos hermanos, convendría certificar noticias. El parentesco, sí, parece muy probable.

26 HRSI, Hisp., 135, ff. 298-299. Modernizo la ortografía y puntuación. El provincial debía ser Bartolomé Pérez. 
El otro hermano es el hermano Pedro Maldonado, de quien Vuestra Paternidad tiene relación, creo yo larga, del padre provincial [¿Bartolomé Pérez?], y por eso no he yo dado [noticia] de lo que de ello supe, de lo que hubo antes de venir a este colegio, y así sólo diré en esta lo que de nuevo le ha pasado. Yo tuve sospecha del hermano [Maldonado] por un hermano a quien él dijo que le habían levantado un gran testimonio, fingiendo contra él que él había escrito una carta que él no había escrito, y que por ella no sería mucho que le viniese mucho daño, y por unas palabras que le dijo de uno que salió de la Compañía que la trasladó, y no sé qué otras palabras.

Inquietud, locos ardides, cartas falsas. El caso incluye escenas extrañas. Aprovechando el sueño del escolar teólogo, su superior, quien algo sospechaba. completó la pesquisa mediante los más expeditivos recursos. Prosigue Castro:

...Una noche le tomé, sin que lo sintiese, unos papeles de sus calzones, porque hubo comodidad, y hallé tres cartas en limpio y un borrador de otra. ...Y comenzando del borrador, era una carta muy tierna y amorosa de aquella persona que Vuestra Paternidad sabe, y era bien verde, y él [Maldonado] me dijo que aquélla había enviado, y de ella había dicho que le levantaban que era suya $[. .$. Y la causa de escribilla dijo fue deseo de salir de la Compañía, y que el día siguiente se arripintió, y le tornó a escribir [a su destinatario diciéndole] estaba loco cuando la escribió, y [que] si no había [aún] ido (como él primero imaginó cuando quiso le despidiesen), no fuese al provincial27; y la causa de esta tentación, y de su embuste, dijo él fue temer que el Padre Provincial habria dado noticia de lo pasado no sólo a Vuestra Paternidad, sino al Vice-provincial.

Maldonado, claro está, temía "por su honor, y esto le apuró". Sin que hurguemos más en sus bolsillos ni conozcamos con exactitud el sentido y antecedentes de las cartas, resulta natural que un mocetón andaluz, entrado en religión aún niño, sufriese en aquella primavera de ardores juveniles, y que por ellos pensase ahorcar hábitos; y a la vez pudo ocurrir que, tentaciones aparte, quisiese mudar de orden religiosa. Había otra carta para el provincial (el padre Bartolomé Pérez de Nueros tenía el cargo cuando a fin de año fue a la Congregación general en Roma). La tercera misiva

27 A juzgar por el castigo, hubo mucho más de imaginación que de acto. Por lo demás el cuadro general es confuso: si Pedro quería provocar denuncias, no se ve por qué acudió a tal expediente. De hecho, aunque buscara una delación, al punto se arrepintió y mandó una segunda carta. 
iba dirigida a su hermano el padre Blas, también jesuita ${ }^{28}$. Continúa el terrible Melchor de Castro:

...al cual [Blas] escribía como ya en el siglo, hablando de vuesa merced $^{29}$, y diciendo que sólo Dios sabía dónde estaba, y que miraría no hacer cosa que desdijese de sus padres ${ }^{30}$.

La última carta se destinaba a otro hermano suyo, seglar, anulando una donación hecha a la Compañia, y enviándole mil reales a cada uno de sus dos hermanos agustinos, y a cada una de sus tres hermanas monjas. Al padre Castro le chocaba que las cartas se enviaran al jesuita Blas y al seglar, y no a los dos mayores, a quienes iba la donación. Todo ello parecía mostrar que éstos lo movían al "tránsito a san Agustín". Para Castro no eran "sus hermanos, en particular el mayor, de muy buenos religiosos, y afectos a la Compañia". Realizadas diversas consultas, el superior castiga a Pedro a encierro y obediencia. El acusado insistió en perseverar como jesuíta y propuso "comenzar de nuevo y tener un año de noviciado en Montilla". Aunque Melchor de Castro se mostró escéptico, el hermano Pedro se salió con la suya y debió aceptarse su ofrecimiento de una nueva prueba. Tiempo después seguía estudios "con provecho". Años más tarde, el provincial Cristóbal Méndez, el 3 de junio de 1596, le escribe desde Montilla a Aquaviva:

[Maldonado] está aquí, no tan bien como se deseaba, y siempre he tenido confianza que con los años tendría más cordura, y soy yo quien puedo testificar de cosas suyas, y aun me pudiera harto sentir y agraviar, porque sé que ha escrito a Vuestra Paternidad cosas bien pesadas, sin fundamento ${ }^{31}$.

El provincial disculpa al muchacho por su inexperiencia, y concluye:

...Lo que ahora puedo decir de él es que está muy mudado. Procede no sólo bien, pero muy bien en su tercera probación y le

28 En San Hermenegildo de Sevilla, 1587, el hermano Blas Maldonado reaparece, a sus 19 años. Debió nacer hacia 1568. Era mayor que Pedro y debió compensar en él por un tiempo la influencia familiar agustina.

20 Melchor de Castro se sorprende, pues, del tratamiento, el cual subrayo.

30 Prosigue aludiendo a una conocida tradición jesuítica: "Aunque la Compañía fuese puerto de salvación, él había de vivir mártir y ocasionado a perderse". Dámaso Alonso se refiere a la creencia en los daños de abandonar la orden, a propósito de Medrano y de Alonso de Santillán (op. cit., vol. I, caps. 4 y 6 ; vol. 2 , apéndice I).

31 ARSI, Hisp. 139, fol. 210r; es el tercer parágrafo de una importante carta. En Montilla se hallaban, recuérdese, el noviciado y la casa de probación. La superación de la crisis mayor en Pedro se advierte en carta del padre Méndez a Aquaviva (Hisp., 136, ff. 79 ss.). 
parece que ahora comienza a ser religioso. $\mathrm{Y}$ el padre Alonso Rodríguez está muy contento de su modo de proceder, y así dará su testimonio por escrito y lo enviará a Vuestra Paternidad. En cosas pasadas de tono no ha habido más, ni sorpresa de ello. Es muy buen ingenio y tiene talento para el púlpito y para leer, y para lo que quisieren emplearle, y está humilde y dispuesto para leer una clase de humanidad, y si esto dura en él... espero será de provecho.

La grande autoridad de Alonso Rodríguez, profeso de cuatro votos, alma de la casa de Montilla, delegado de la Bética a congregaciones generales, respetadísimo escritor ascético, tuvo que resultarle salvadora a Maldonado. Cumplido un breve "segundo noviciado", continuó teología y pasó a la última probación, que en la regla jesuítica corresponde a la época de la ordenación sacerdotal. Lo llaman aún hermano en esta etapa. Siempre como hermano se halla en 1597, a los veintitrés, en el pequeño e incómodo colegio de Málaga; salud sólo mediana; lee gramática. Anota el catálogo: "Ha acabado sus estudios y tercera probación, y hace algunas pláticas en cárceles y plazas; ha sido procurador". Allí en Málaga conoció al padre Blas Valera, mestizo peruano, autor en latín de una historia de los incas y la conquista, quien había llegado a Andalucía tras un castigo que tuvo por solicitante: un desliz que al parecer tuvo en Potosí. Valera había vivido antes en Cádiz, y sus originales quedaron truncos y estropeados a consecuencia del saco e incendio de la ciudad por los ingleses, en 1596. Valera murió en 1597 y sus escritos quedaron en manos de Maldonado ${ }^{32}$. Pronto la situación va a cambiar y Maldonado, ya como padre se traslada a casas importantes: el colegio de Córdoba, en 1599; figura con el núm. 20. Allí se encontraba Martín de Roa y, acabado de llegar, Alonso Rodríguez. El sevillano goza de buenas fuerzas y lo dedican a enseñar gramática y Escritura; también confiesa y predica ${ }^{33}$. No estaba mal dictar cátedra para teólogos a los veintitrés años, y más en Santa Catalina de Córdoba; allí la habían dado eminencias como Prado y Pineda. Merecía, pues, confianza y estima.

Por entonces le proporciona al Inca Garcilaso, gran amigo de la Compañía, los papeles destrozados de Blas Valera. "Hízome mer-

32 Cf. el prólogo de Francisco Mateos, a la anónima Historia general de la Compañia de Jesús en el Perú, Madrid, 1944, voi. I, p. 62. Más noticias en Mon. Hist. S. I., Monumenta Peruana, ed. de Antonio de Egaña, Roma, 1954, ss., vols. I-III.

33 Tras Jerónimo de Prado, Juan de Pineda había ilustrado la cátedra de Escritura en Santa Catalina de Córdoba. La casa malagueña, en cambio, era modesta y "ruin" según la documentación jesuítica. Otro biblista famoso, Juan Bautista de Villalpando, continuador de Prado, había enseñado en Córdoba otras materias. 
ced de ellos -cuenta el Inca- el padre maestro Pedro Maldonado de Saavedra, natural de Sevilla, de esta misma religión, que en este año de mil y seiscientos lee Escritura en esta ciudad de Córdoba"34. Tan singular merced, hecha a un hombre que como Garcilaso no pertenecía a la orden, fue obra de este inquieto mozo y fruto de un azar, quizás de un impulso, bien propio de Maldonado.

De pronto, cosa no habitual en la Compañía, el joven jesuita cambia de provincia y se traslada a la Casa Profesa de Valladolid, es decir, junto a la Corte. En el catálogo de esa residencia en 1602 se registra con el núm. 7: sevillano, de treinta años (sic), diecisiete en la orden, con buena salud. "Lee teología y predica". Todo ello es fidedigno, pero hay detalles que resultan oscuros. Un catálogo del colegio de Córdoba, enero de 1603, da noticias sobre él que mejor corresponden a 1602: aparece a los veintinueve de su edad y con dieciséis de jesuita; le dan el núm. 17; había enseñado latín tres años y cuatro Sagrada Escritura ${ }^{35}$. Ese 1603 del catálogo andaluz cabe remitirse a 1602, a fines, cuando debieron redactarse los informes trienales para enviarlos a Roma. Puede también que en Córdoba considerasen a Maldonado sólo temporalmente ausente. El catálogo de la Profesa vallisoletana, aunque fechado en 1602, vale para el año siguiente, el cual rige para toda la Provincia Castellana. De un modo u otro, consta que acababa de estar en Córdoba y no se sabe cómo ni por cuánto tiempo lo destinaron a Valladolid. Es claro asimismo que la mudanza no significaba castigo, pues iba a un lugar excelente, donde se le dio cátedra de teología y el ministerio de predicar en esa importantísima ciudad. ¿Cómo llegó allí? El apoyo de su hermano Melchor, procurador en la Corte y premiado por el rey en 1604, debió ayudar; Pedro era un mozo brillante, muy promisorio, cuyo comportamiento en Córdoba sin duda satisfizo; había ganado renombre en el púlpito y ello era entonces apreciadísimo. A un lucido orador sagrado se le invitaba a venir de lejos en grandes ocasiones: desde Roma pensó Aquaviva encargarle sermones de Adviento y Cuaresma en el reino de Aragón, para satisfacer un pedido especial. Como “joven y predicador" lo presentará muy pronto el cardenal Ginnasio,

34 Comentarios reales, lib. I, cap. 6; la obra quedó completamente terminada en 1604 y el Inca no consigna que su amigo cambió de religión. Se equivoca al llamarlo "maestro" pero acierta en el Saavedra. No se olvide que el padre de nuestro Maldonado, el coronel don Melchor, peleó en las Alpujarras, adonde Garcilaso llegó a capitán. ¿̨Se conocerían allí? Nada sabemos.

35 A juzgar por ese catálogo de la Profesa, fechado en 1602 a diferencia de otras casas de la Provincia Castellana, calculo que Pedro llegó poco antes de 1603, quizás mudándose a la Corte en circunstancias especiales (cf. infra, nota 37 ). 
nuncio en España ${ }^{36}$. Alguna recomendación de un poderoso debió mediar, pues consta que el general jesuíta Aquaviva no lo juzgaba apto para residir en la capital del reino.

Más tarde, el 8 de octubre de 1604, Aquaviva escribirá de Maldonado: "Yo nunca quise que fuese a la Corte, resistiendo como pude, como quien conocía lo que ahí es menester, y por ese particular echará de ver Su Excelencia [Lerma] no echar mano de sujeto sin tener aprobación del superior que se conoce mejor" 37 . La curia romana, pues, tuvo presente los anteriores problemas del mozo, así los hubiera superado.

\section{LA GRAN BORRASCA}

Muy pronto, casi al llegar, pienso que en 1603, ganó el aprecio del valido. Bien lo expresa el nuncio Ginnasio: "Un Padre Maldonato, Giesuita della Provincia di Siviglia... gia molto favorito del Sr. Duca di Lerma". Así empezaron los hechos que engolfaron y atormentaron al mozo. Recapitulemos: existía gran desasosiego entre los jesuitas de Valladolid. Las causas y alcances de tal situación se conocen en buena medida. Hubo quejas de unos pocos y algún memorial, refiere Astrain, a lo cual prestó oídos el nuncio, según lo escribió al Papa, 3 de febrero de 1603. El caso acabó preocupando a Lerma. Meses después todo se complicó por el serísimo problema personal del padre Fernando de Mendoza, antes apuntado. Era confesor de la condesa de Lemos, cuyo marido acababa de morir siendo virrey de Nápoles. En Italia el jesuíta Mendoza fue un quebradero de cabeza para su orden, pues la condesa gozaba -y continuó gozando- del apoyo papal, y en Valladolid el del nuncio Ginnasio. Vuelta a la corte española esta gran señora, llegó tras ella el padre Mendoza, en julio del mismo año. Terrible desventura, pues la condesa tenía tanto poder sobre su hermano Lerma como Mendoza sobre ella. Mendoza era un religioso relajado, y obtuvo los más desusados privilegios. Su conducta dañaba

36 Archivo Secreto del Vaticano, Nunziatura di Spagna, 59, ff. 246-248. Astrain usa, citándola, esta carta, básica aquí. En cuanto a don Melchor, hermano de Pedro, fue procurador mayor de Sevilla "muchos años en la Corte, donde conocido su talento por el rey Felipe III, le dio sin pretenderlo el oficio de Tesorero, Juez y Oficial de la Casa de Contratación de Sevilla el año de 1604" (MatuTe, Hijos..., vol. II, p. 195). Resulta lógico que Melchor ayudase a Pedro a pasar a la Corte, y asimismo que éste interviniera en tan codiciado nombramiento, retornando con creces el servicio. Todo ello sugiere que en parte de 1604 el padre Maldonado andaba aún en buen pie.

37 De Claudio Aquaviva al P. Gabriel de Toro, ARSI, Castel, VII, I, Epist. Gen. 1603-1606, fol. 89r. 
a la Compañía, por más que ésta contara con personas respetadísimas como el padre Ricardo Haller, o bien el padre Luis de la Puente, por quien se tenía la más alta estima ${ }^{38}$. Nada le resultaba más peligroso a la orden que el tener al inquieto Maldonado cerca del duque, pero ya era tarde. Mendoza empezó a intrigar muy pronto; en septiembre tuvo un serio encuentro con Haller; más adelante, desavenencias con Maldonado. Según Astrain el duque intervino en varios casos de jesuítas, cuya fecha no especifica. Los hechos aquí se complican y me limito a lo más probable, intentando ordenar lo ocurrido.

Desde Valladolid, en mayo de 1604, Maldonado le envía a su general carta que sólo se conoce por la respuesta, a 28 de junio. Ya andaba Pedro harto angustiado en esa primavera, lamentándose ante gentes de la corte por errar al "hacerse instrumento de otro personaje"; dijo en otra ocasión "que el diablo le había dado a conocer a fulano". Aquaviva a la vez lo reconforta y le llama la atención. Maldonado le ruega con "instancia, salir de la corte". El general sugiere que vaya a Valencia, donde le reclaman un buen predicador para Adviento y para Cuaresma, es decir la de 1605; este ofrecimiento llegará tarde ${ }^{39}$. Maldonado, como se ve, pasaba apuros, pero todavía en la primera mitad de 1604 circulaba por los palacios y mantenía el apoyo de Aquaviva.

Por aquellos meses, cuando el joven jesuíta aún andaba en buen pie, Lerma y el propio Felipe III criticaron ante él a quienes gobernaban su orden. Con el acuerdo del rey y el duque, Maldonado resolvió actuar directamente, escribiéndole al padre general sobre el caso. Ya establecido el conducto, Aquaviva le contestó a Su Majestad y al privado mediante el mismo Pedro. Lo refiere algo después el propio general, cuando la tempestad ya había estallado. Dirigiéndose a Joseph de Villegas, prepósito de la Profesa, le dice que nunca le dio a Maldonado

...comisión ninguna para que allá tratara con Su Majestad ni con el Duque de Lerma, sino que acá lo supimos después de hecho, escribiéndonoslo harto moderadamente el mismo padre [Maldona-

88 Lo recuerda el padre Abad en su introducción a LuIs dE LA PuENTE, Obras, op. cit.; id., Vida y hechos del V. P. Luis de la Puente, Comillas, 1957. También este ilustre varón fue maestro de novicios en Villagarcía, cerca de Valladolid.

39 Aquaviva a "Pedro Maldonado, en Valladolid", Roma, 26 de julio de 1604; Epist. Gen., loc. cit., fol. 74v. Hay otra carta al provincial Alonso Ferrer, donde toca el punto. Por ella sabemos que Maldonado se quejaba de que "el predicar tan a menudo, como estando ahí es forzoso que lo haga, no le ayuda mucho para su salud". En otras cartas se habla de malestar físico, antes no señalado en los catálogos, lo cual coincide con las tensiones de aquellos días. 
do], el cual, viendo que dos personas tan calificadas se quejaban del gobierno de la Compañía, hizo lo que debía a religioso en suplicarles que, pues sentían aquello, dejasen poner el conveniente remedio a los superiores; y así entonces le agradecimos este trato oficial que había hecho; y pues Su Majestad, y el Duque por su medio, me significaron lo remediase, antes se habia apuntado que el Rey mismo me escribiese sobre ello, yo no veo cómo algunos me cargan ahora de haber cometido negocios tan graves al P. Maldonado, pues no hicimos otra cosa que responder y agradecer la merced por el mismo medio, encargándole que presentase las cartas ${ }^{40}$.

Al mismo tiempo existía un comisionado especial, el padre Diego de Sosa, dedicado a aquellos problemas de Mendoza. Aquaviva, pues, excusa a Pedro, aunque también deplora las imprudencias de éste. Esto se escribía en Roma el 23 de agosto, cuando la definitiva caída de Maldonado había ocurrido ya sin que su general lo supiese.

Los hechos sucedieron vertiginosamente. Las cartas entre Valladolid y Roma tardaban unas veces cinco semanas y hasta dos meses y más. Entre el vendaval desatado en la Corte y la contestación de la Curia mediaba un tiempo indefinido que dificultaba cualquier solución. Momento hubo en que Aquaviva hubo de responder, juntas, a cuatro cartas del provincial castellano, Alonso Ferrer. Vemos así al mozo Pedro unas veces lleno de angustia, otras interviniendo en el corazón de la corte real y, en muy pocas semanas, castigado y hundido.

Cuando llegaron las cartas al rey y al duque confiadas a Maldonado, cundió la especie de que le habían encomendado castigar a Mendoza y secuaces. Cuenta esto la relación del padre Haller, que resume Astrain ${ }^{41}$. El mismo Haller creyó, erradamente, aquella suposición, sin duda alimentada por torpezas e indiscreciones de ese joven jesuita metido a palaciego. Pronto se agrandaron los rumores, los cuales ahora afirmaban que un importante superior, el padre Hernando de la Cerda, compartía la misión contra Mendoza. No le faltaban a éste medios para defenderse ni le sobraban escrúpulos. Calculo que esto debió pasar a fines de junio o primeros de julio. Una calumnia se esparció y llegó a oídos de Lerma, quien le dio crédito. Carta del nuncio al cardenal Aldobrandini fechada en 10 de julio nos informa: culpaban a Cerda de infamar

40 Roma, 23 de agosto de 1604; Epist. Gen., loe. cit., fol. 77v. Aquaviva explica que contaba con un doble conducto, aludiendo sin mencionarlo al padre Sosa, cuya misión refiere Astrain.

41 Antonio Astrain, op. cit., vol. III, p. 639; el texto, fechado en Valladolid a 5 de marzo de 1605, se halla en ARSI, Cast., Hist., vol. I, núm. 34; el padre Haller tuvo al parecer una actitud favorable a Maldonado. 
la honra de la condesa de Lemos y el duque enfureció al ver manchado el nombre de su hermana. El nuncio, siempre obsecuente con Lerma, e inclinado al bando de Mendoza, expulsó de Valladolid a Hernando de la Cerda a su nativa Galicia e hizo que castigasen a Maldonado.

Según Astrain el atolondrado muchacho "fue recluido en el colegio de León" - lugar donde residía el homónimo. Todo pudiera ser, pero yo pienso que lo despacharon a Valencia. El mismo historiador consigna, al narrar esos embrollados acontecimientos, que en algún momento el duque lo "desterró" a esa ciudad. Hay pruebas de que el malaventurado anduvo allí por entonces.

Curiosa cadena de coincidencias la de nuestro personaje a lo largo de su vida. Justo cuando Claudio Aquaviva le proponía como grata solución ir a predicar durante varios meses a la capital levantina, resultó yendo por bien distintas razones. Informó él mismo del viaje a su general, el 8 de julio, según la respuesta de Aquaviva: "Entendí lo que ha pasado en esa Corte cerca de su salida [de Maldonado] y del padre Cerda, la cual he sentido como es razón". El 10 de julio le envió noticias de lo ocurrido el prepósito Villegas, a lo que contestó el general: "Acá no supimos de la ida a Valencia del padre Maldonado hasta que V. R. y otros nos lo escribieron". Años más tarde, aludirá Pedro a su paso por allí; cuenta que en "el real de la ciudad de Valencia oí a uno de los mayores señores deste reino, que siendo en aquella ciudad Virrey había acontecido" 42 ; se trata de una simple anécdota; ella lo presenta cerca de grandes personajes. No hay noticia de que hubiera viajado allí en otra ocasión.

Más bien fue salida, como escribe Aquaviva, que destierro; si fue esto último, o bien se conmutó o tuvo un carácter momentáneo. De hecho, cuando ocurrió el escándalo de principios de agosto, Maldonado debió hallarse en Valladolid o en sus alrededores, así fuera recluido. Una carta que no llegó a enviarle Aquaviva, tachada, se dirige a él como si estuviera "en Villagarcía" (23 de agosto de 1604). No parece que fuera Villagarcía de Arosa, provincia de Pontevedra, más importante, sino Villagarcía de Campos, a seis leguas de Valladolid, donde la Compañía tenía casa para noviciado y tercera probación. Paradójicamente, el padre Maldonado estaba a punto de realizar la definitiva profesión, la cual, por increíble que parezca, se hizo en lo peor de la tormenta. Se

42 Aquaviva, Roma, 23 de agosto de 1604, a "Pedro Maldonado en Villagarcia"; original tachado, que el general sustituyó por otra carta de igual fecha; ambas son importantes (Epist. Gen., loc. cit., ff. 7v y 81v); ya cité la carta que el mismo día envió a Villegas (cf. supra, nota 40). La salud de Pedro flaqueaba. En toda esta parte Astrain es insuficiente. 
la concedió el provincial de Castilla, Alonso Ferrer. Si ello ocurrió en León, codo a codo con su homónimo, las coincidencias - siempre posibles- llegarían al colmo.

En aquellos días, momento de recogimiento espiritual para cualquier religioso, Pedro no andaba para solemnes profesiones, sino herido por la injusticia y las maquinaciones de Mendoza. El atolondrado Pedro se confundió más y más. Cegado por sus antiguos humos de poder, pudo creerse dueño de una astucia política de la que carecía. El Privado debió haberse escrito meses atrás. Convencido de que su desgracia era obra de Mendoza, Maldonado preparó un plan digno de la más enrevesada comedia; o en rigor un embrollo en que recrudecieron sus antiguos desvarios. Valiéndose de un estudiante como amanuense, inventó cartas exageradísimas que lo calumniaban, pensando que al verificarse los hechos quedarían probadas su propia inocencia y la culpa de Mendoza. Se enviaron a grandes señores, al nuncio, al confesor del rey. Había llegado muy lejos.

Todo esto debió suceder al terminar julio. Cabe imaginar el revuelo. El padre Ricardo Haller creyó que se trataba de una infamia contra Maldonado; pero no: ya el 2 de agosto el padre Diego de Sosa, comisionado especial, le envió a Aquaviva copia de las cartas; el 7 partió la información del prepósito Villegas. El mismo día mandó al Vaticano una larga relación el nuncio Ginnasio, exclusivamente dedicada al infeliz sevillano, poniéndolo como no digan dueñas. El original, que guarda el Archivo Secreto, lleva un comentario de Clemente VIII. Para el cardenal Ginnasio, Maldonado era un "simulatore", y entre otras lindezas lo llama "doble como una cebolla" 43 . Refiere cómo había sido favorito del duque, a quien más tarde, y también al rey, le habló "muy mal" del padre Mendoza. Pinta la consternación de Lerma al advertir cuántos secretos conocía su antiguo protegido; el duque llegó a creer que el mozo había intervenido en otras intrigas. Cuenta Ginnasio que en la carta que él recibió se presentaba al joven jesuíta como "vicioso", pues anduvo "otras veces encarcelado por el vicio nefando". Tales acusaciones eran para él fabulosas, no obstante su escasa simpatía por Pedro, lo cual prueba la buena reputación de éste en cuanto a honestidad. La invención, afirma el nuncio, pretendía culpar a Mendoza, convirtiéndolo en difamador de Maldonado.

43 Fray Pedro Maldonado, O. S .A., Primera parte del Consuelo de iustos, Lisboa, 1609, lib. II, cap. 5, pp. 67-68 (la paginación del volumen es anárquica). La carta del nuncio cardenal Ginnasio, ya citada, es del 7 de agosto (cf. supra, nota 36); la tengo presente en todos estos sucesos, así como las que escribió Aquaviva por entonces, referidas en la nota anterior. 
Es curioso que al principio lo presenta como expulsado o desterrado ("cacciato") de la Corte por "poco prudente"; y al terminar recomienda que "a este hombre" lo envien "allá", a Roma, "donde hubiese mayor comodidad para interrogarlo y darle el debido castigo". Según ello, el acusado no se hallaba suficientemente lejos de Valladolid.

Escribe Ginnasio que Maldonado admitió su culpa, y confesó también haberle escrito contra sí mismo al Papa y a su general, "para no ser admitido a la profesión", lo cual el nuncio juzga "poco creíble". En rigor, las febriles vacilaciones de años atrás habían retoñado en Pedro como parte de una gran crisis. Nuevamente osciló entre la fidelidad a la Compañía y el deseo de abandonarla. ¿Para qué entonces ese autoacusarse, al parecer hasta de culpas inexistentes? No es momento de entrar en diagnósticos de moderna psicología, quizá demasiado fáciles. Baste reconstruir el caso, que bien lo merece.

Nuevo lance teatral: cuenta el cardenal Ginnasio que "el buen provincial", Alonso Ferrer, andaba otorgándole la profesión cuando llegaron -corriendo quizás- algunos jesuítas, con el escándalo de las cartas fingidas. El provincial no se detuvo. Noticias de Aquaviva muestran su preocupación por el asunto, y suavemente le había recomendado a Pedro "una poca dilación a la profesión"; tales palabras llegaron a destiempo. Más adelante el general reconvino a Ferrer: "Harto más acertado fuera que se hubiese diferido" 44 . El solemnísimo acto, momento decisivo en la vida de un religioso, acabó así en tragicomedia.

Al mismo Alonso Ferrer, provincial castellano residente en Valladolid, le tocó abrir proceso y juzgar a Maldonado. El reo debió contar con argumentos y respaldo, pues no se le despidió; pudo haber atenuantes que merecieron consideración: al cabo había sufrido injusticias, a consecuencia de la calumnia contra Cerda, y el nuncio cuenta que para Maldonado su expulsión de la Corte la causó Mendoza mediante la condesa. La sentencia final parece haber sido a reclusión y penitencias. Dámaso Alonso comenta con perspicacia las noticias de Astrain. "Toda esta historia", piensa, "no deja de ofrecer hoy sus oscuridades. Prescindiendo ahora de sus relaciones con Lerma, parece que en la lucha del rebelde $P$. Mendoza con sus superiores, el P. Maldonado representaba en medio de todo la opinión de la Compañía, pero que, atolondrado y zascandil por naturaleza, se excedió lamentablemente, llegando a

4 Aquaviva a Maldonado, el 23 de agosto (cf. supra, nota 42). Al provincial de Castilla Alonso Ferrer el 20 de septiembre de 1604 (loc. cit., fol. 86r Y v; algunos de estos documentos se conservan en microfilm). 
la comisión de un verdadero delito"45. Hoy sabemos que tales disparates tuvieron antecedentes en Maldonado, justamente antes de ordenarse. Ahora ocurrieron al profesar: sólo que esta vez andaba en muy distinta situación, peleando contra enemigos enconados, ante las cabezas del reino.

La reacción de Aquaviva se conoce por tres cartas, fechadas todas a 20 de septiembre de 1604. En ellas muestra a la vez consternación, piedad por el enloquecido sacerdote e inquietud por el daño que en tan mal momento recibía la orden. Baste lo referente a nuestro personaje. Al provincial Ferrer, juez de la causa, le expresa gran pesar por la suerte de Maldonado y añade: "Verdaderamente se puede creer que no estaba en si, pues echándose a perder tan a la clara, no lo advertia. Bien está en su penitencia hasta que V. R. haya visto todo". A Joseph de Villegas, prepósito de la Casa Profesa, a quien sigue tratando como al superior inmediato de Pedro, le dice que éste "no estaba en si cuando hizo cosas semejantes, con las cuales se ha echado a perder totalmente". En la carta al padre Sosa, citada por Astrain, insiste: "... Nos hemos maravillado harto, y más de la fuerza que la melancolia tuvo en el P. Maldonado. Dios le perdone, que tan a la clara se ha echado semejantes cosas. V. R. le anime y exhorte que haga la penitencia con humildad y recogimiento... aunque nos ha atado las manos"46. Consta además que los superiores protegieron a Maldonado, impidiendo que noticias peligrosas se extendiesen.

Para Astrain aquí concluyen las referencias a Maldonado; Dámaso Alonso lo reencontrará, ya agustino. Cabe esclarecer esta breve etapa. El reo sale absuelto de otras acusaciones que, según Aquaviva, tanto pudieran "ofender al duque"; pronto éste "se va desenconando" en lo de su antiguo favorito. A principios de octubre Maldonado apela y el general le escribe al padre Ferrer que aguarda ver el proceso, y comenta "que la pena antes ha sido poca que mucha”. Ya el 13 de diciembre acusa recibo de la sentencia. Por lo visto, el sevillano pensó continuar en la orden; luego desistió de la apelación, en carta que le envió a Aquaviva desde Andalucía: ya andaba de vuelta allí a primeros de 1605 , pues el 7 de

$45 O p$. cit., vol. I, p. 41. Adviértase cómo le concedieron la profesión a Maldonado, aun hallándose en gran dificultad. Dámaso Alonso recuerda que el profesar y el número de votos tuvieron gran importancia en tiempos de los memorialistas. Claro que a esas alturas Pedro no iba a ser un jesuita profeso de cuatro votos, como por ejemplo lo eran Prado y Melchor del Alcázar en la lista general de la Bética, 1590.

46 Loc. cit., ff. 85r-86v. El 8 de octubre Aquaviva le escribe al provincial Ferrer: "Hizo bien del cuidado que puso en la guarda de los papeles, por la conveniencia de no andar en muchas manos" (fol. 87v). 
febrero el general así lo indica ${ }^{47}$. Sin duda ya había resuelto Maldonado pasar a San Agustín. La dimisoria la firma Claudio Aquaviva el 12 de diciembre de 1605 y el asunto queda a cargo del provincial de la Bética, Melchor de San Juan. Justamente el superior que Pedro había tenido en Córdoba hacia 1602, antes de ir a la Corte.

La dimisoria concede licencia, dentro de tres meses a partir de la fecha, para pasar a cualquier orden religiosa de regular observancia. Debido a las demoras epistolares y trámites finales Pedro no debió salir hasta principios del año siguiente. En los catálogos trienales de la Bética de 1606 todavía figura en el colegio de la Compañía en Cazorla, con el núm. 7, a sus treinta y dos años $^{48}$. Pasó, pues, todo 1605 aún como jesuita, ya vuelto a su antigua provincia. Fue mala época en la región, pues volvió a la pavorosa pestilencia llamada secas o landre. De entonces proviene su "Discurso a la Andalucía en la seca del año de 1605", incluido luego en uno de sus libros". Alude allí a las continuas desgracias de "las casas apestadas y agora los campos secos". Ya andaba a punto de abandonar la Compañía.

\section{LA ÚLTIMA ETAPA}

A los pocos meses y en Sevilla, Maldonado dio a luz en forma anónima una obra harto significativa: Discurso del choro y officio divino. Compuesto por un Religioso de la Orden de san Augustin. ...Dirigido a doña Eluira Maldonado monja del insigne Conuento de san Leandro, 1606. Al fin del texto reza M.DC.VII, probable fecha final, pero la licencia, de fray Pedro de Valderrama, es a 23 de junio de 1606, y la del provisor a 14 de julio. Ni entonces, ni cuando en 1609 publicó a la vez cuatro libros diferentes en

47 Cf. la citada carta a Ferrer del 8 de octubre y otra de igual fecha, mencionada también, a Gabriel de Toro (cf. supra, notas 37 y 46). Al escribirle al provincial el 15 de noviembre, Aquaviva no había admitido aún la apelación de Maldonado; en diciembre de 1604 llega tardíamente la sentencia. Ya el 7 de febrero de 1605 escribe: " $\mathrm{La}$ copia del desistimiento que el padre Maldonado ha hecho de su apelación se ha recebido, y antes la teníamos ya, por habérnosla enviado de Andalucía" (loe. cit., ff. 99v, 107r y 117r).

48 HRSI (Dimissi), Hist. Soc., 54, fol. 20r. Debo la indicación al P. Miguel Batllori, en carta fechada en Roma, 11 de junio de 1975.

49 Fray Pedro Maldonado, O. S. A., Traça y Exercicios de vn oratorio, Lisboa, 1609, lib. IV, fol. 89 ss., sign. S-2; la paginación de este libro, como la del Consuelo de justos, es caótica, tanto en los ejemplares de la Biblioteca Nacional de Madrid como en los que poseo. Hay otras referencias a conventos agustinos. Me refiero al Discurso sobre el landre en "El Inca en los años aciagos", en Anuario de Filología, Maracaibo, 1966, p. 147. 
prensas lisboetas, dio muestras de haber tenido dificultades económicas para la impresión. Sorprende por qué no vio luz también su opúsculo sobre el Privado.

El Discurso del coro, como el título indica, es un encendido elogio de la oración vocal y en comunidad, lo cual, es bien sabido, no se practica en la regla de Loyola. Expresa así un viejo desacuerdo y una visible preocupación por justificar el cambio de orden con agresividad indirecta pero clara. El anonimato, sólo a medias encubierto, de ese pequeño libro, es típico del espíritu complicado del autor, a la vez que revela impaciencia en aquellas prisas por editarlo. Si años atrás preparó cartas en las que aparecía como si hubiese dimitido sin que ello hubiese ocurrido, ahora cabe preguntarse si la redacción, o al menos la idea de ese Discurso, no hubiera nacido antes de su egreso oficial de la Compañía. En 1609 lo reimprimió dentro del Consuelo de justos, aclarando la paternidad de la obra. En la primera edición anónima, en la dedicatoria a su hermana Elvira, confiesa deberle "el ser a sus oraciones", y añade que "aunque calla su nombre [de autor], porque pasa la vida en silencio y esperanza, algún día conocerá por suyo este hijo, y lo pondrá a una mesa con otros, más dignos de su padre, que sacará a luz, pues no está seco ni muerto el corazón"so. En otro volumen aparecido el mismo año, Traza y ejercicios de un oratorio, dice que "hízose despacio e imprimióse de priesa"Ђ1. Allí, como en otros escritos suyos, insiste en las excelencias de la oración vocal: así escribía un alumno del típico ignaciano Alonso Rodríguez. Al prologar en 1609 la reimpresión del Discurso del coro, fray Pedro afirma haberlo compuesto "en el noviciado del estado donde Dios me llamó" 52 , o sea durante la breve prueba que pasó al hacerse agustino, a principios de 1606; cabe pensar que esta explicación fuera simple excusa, y que la obrita se hubiere concebido antes.

50 El Discurso del coro, siempre anónimo, se reeditó en Barcelona, 1908, ya bajo el nombre de su autor, fray Pedro Maldonado, en el Consuelo de justos, trat. II, ya citado. Lo advierte Gregorio de Santiago Vela, op. cit., p. 88.

51 Ello se ve en la composición tipográfica, irregular, y en la desordenada paginación de la Traza, salida de las prensas de Jorge Rodrigues, y el Consuelo, que editó Pedro Craasbeck; cf. Dedicatoria. Maldonado ocupó a la vez en ese mismo año los talleres de Vicente Alvares, para sus Commentarii in Psalmos Dazid, y los de Juan Alvarez para las Lectiones sacrae in primam canonicam B. Joannis Apostoli; ambos volúmenes, como observa Santiago Vela, se imprimieron también "en variedad de tipos". En casa de Pedro Cransbeck había publicado Garcilaso en 1605 su Florida del Inca, y justo en 1609 la primera parte de sus Comentarios, en que nombra a Maldonado; pero el procurador de Garcilaso en Lisboa fue el hermano Ferraz, jesuita.

52 Consuelo de justos, prólogo al trat. II. 
Palabras reveladoras: al prologar la Traza, Maldonado de Saavedra dice que así como el Nilo, el Guadiana y otros ríos se esconden y renacen, también las vidas se ocultan en los oratorios y entonces salen con mucho mayor caudal que cuando "se escondieron, y con más aliento y brío". Debió escribir esto en Lisboa, 1608, cuando andaba cuidando la impresión simultánea de sus obras, alojado en el convento de Nuestra Señora de Gracia ${ }^{53}$. No bien acabó este empeño volvió a España, y entre mayo y junio de 1610 le bastaron unas pocas semanas para graduarse, en la Universidad de Osuna, como bachiller, licenciado y doctor en teología. Tanta rapidez no parece frecuente, pero tampoco resulta inusitada, pues algo semejante ocurrió años atrás con otro escritor agustino, fray Hernando de Zárate ${ }^{54}$. Todo muestra que su nueva orden lo recibía con los brazos abiertos y es evidente que contó con padrinazgo tan distinguido como el de fray Pedro de Valderrama, célebre orador sagrado, orgullo de Sevilla, cuyo retrato se conserva por obra de Pacheco. Valderrama, quien había sido alumno de los jesuítas, guardó con ellos excelentes lazos, a juzgar por sus sermones. Fue hombre de buena pluma, y en sus páginas se descubren con placer pasajes felices. Tanto el Discurso del coro, aún anónimo, como las cuatro impresiones lisboetas de Maldonado llevan todas aprobación de Valderrama ${ }^{55}$. Tenían ambos frailes algo en común:

65 Maldonado debió residir en la capital portuguesa al menos un año, y abundan pruebas de que allí concluyó sus libros, por continuas referencias a gentes o tierras lusitanas, tanto en el texto como en preliminares: "Desde que entró en este convento de Nuestra Señora de Gracia", escribe al dirigirle el Consuelo a la monja lisboeta "Felipa de la Madre de Dios, primero Virreina de la India"; también se refiere a "un docto y curioso médico de esta ciudad de Lisboa (ibid., lib. II, p. 181r), etc. Las menciones de figuras de la Compañía, como Francisco de Borja, o de autores como el cardenal Toledo, existen, pero son escasas.

54 Cf. Santiago Vela, op. cit., s. v. Zárate, importante autor ascético, había enseñado antes en esa misma Universidad de Osuna.

ss Hay noticias de Valderrama en Francisco Pacheco, Libro de ... retratos, ed. de J. M. Asensio, Sevilla, 1885; lo recuerdan también Rodrigo Caro, Ortiz de Zúñiga y sucesores. A Valderrama se refiere Medrano en la carta a Pacheco que publica Dámaso Alonso (II, p. 320). En su póstumo Teatro de las religiones, Sevilla, 1612, Valderrama menciona a autores jesuítas como Juan Maldonado, Pineda, Prado y Martín de Roa. En su elogio de Ignacio de Loyola en las fiestas de beatificación, apunta que la Compañía suprimió el coro, indicándolo sin acritud (p. 604). Es probable que otros sermones, como el de San Hermenegildo, se dijeran en iglesias de los jesuítas. Debió ser gran diplomático, pues el Tratado de las religiones dedica buena parte a santos de otras órdenes, resanando asi llagas y cicatrices como las que había provocado otro agustino, el cronista Hierónimo Román, en obras históricas. Valderrama, provincial andaluz entonces, firma las licencias de impresión de fray Pedro Maldonado; también lo hizo el padre Aste, general de la orden. Tuvo el nuevo agustino las mayores facilidades: viaje a Lisboa, bien lejos de la corte espa- 
dotes notables para el púlpito ${ }^{56}$. A Maldonado se le recordó por ello en Andalucía, igual que por su trueque de hábito: una apostilla anónima, de letra contemporánea, escrita al final de la dedicatoria en un ejemplar de la Traza, apunta: "Este padre, siendo de la Compañía, predicó un gran sermón en la beatificación de San Jacinto de la orden de Santo Domingo, en Granada" ${ }^{2}$.

Murió en San Agustín de Sevilla, en 1614, a los cuarenta o cuarenta y uno de su edad, con fama de "religioso ejemplar y muy humilde", al decir del padre Santiago Vela. La carta "bien verde" que le pilló Melchor de Castro había quedado atrás; el provincial jesuita Cristóbal Méndez miró lo sucedido como fiebre juvenil, sin mayor culpa. En cuanto a los desaforados acontecimientos de Valladolid, una vez calmado Lerma, tampoco impidieron la plena rehabilitación. El bullicio ocurrió lejos y el mozo había sido primero injusta víctima. Fuera de este alboroto su comportamiento no causó reproches. Muchos lo juzgaron imprudente, alocado, algunos lo presentaron como gran ambicioso, pero hasta donde sé, nadie alegó otras culpas. Muertas las esperanzas cortesanas, todo lo borró el tiempo. Ello se alcanzó gracias al ánimo tenaz del atribulado Pedro, a la ayuda de sus superiores - jesuitas y agustinos-, al aprecio que merecía y, por qué no decirlo, a su buena estrella. Debió contar también el apoyo familiar. Nadie en 1604 hubiera pronosticado final tan favorable.

Cuando Aquaviva lo creyó pasajeramente enajenado debió estar en lo cierto. Una gran voluntad y a no dudarlo consejos oportunos le bastaron a Maldonado para superar aquella hondísima crisis, que tocaba lo intimo de su personalidad y afectaba sus nervios. Hubo momentos en que se declaró enfermo, e impedido de viajar a Roma. Salió de aquel abismo sin auxilio de médicos y gozó en sus últimos años de la estima general.

\section{ÚLTIMAS OBSERVAGIONES}

Debemos a Dámaso Alonso la primera biografia seria de Francisco de Medrano, infinitamente superior a cuanto antes existia. Piensa allí que tanto el poeta como su amigo Maldonado hubieran egresado por ser ambos, en diversa medida, jesuítas rebeldes. No

ñola; impresión simultánea y rapidísima de sus obras, en cuatro volúmenes; grados académicos en un santiamén. La orden y su provincial le abrieron los brazos. Valderrama murió en $\mathbf{1 6 1 0 .}$

56 Aparte la documentación epistolar, consta en sus biógrafos, desde Nicolás Antonio y Ortiz de Zúñiga hasta el padre Santiago Vela.

57 Ejemplar que poseo; resuelvo abreviaturas y modernizo la ortografía. 
faltan puntos de semejanza, aunque lejanos. Fruto de un largo y complicado proceso, la salida de Maldonado se resolvió finalmente por un especialísimo cuadro de circunstancias. Desde su primera juventud hubo, sí, extraña incomodidad, abierto desacuerdo con el espíritu ignaciano, según se manifiesta luego en el Discurso del coro; es obvio que en ello contó el influjo de sus varios hermanos agustinos. Las dificultades que tuvo Pedro como escolar fueron crisis juvenil y tuvieron carácter personal en gran medida. Nada de ello se ve claramente ligado a luchas internas de la Compañía. La agitación de los memorialistas, muy anterior, pudo, sí, influir tardíamente en el caso de Medrano, quien siendo aún jesuíta no vaciló en dedicarle un poema a José de Acosta, hallándose éste en desgracia ${ }^{58}$. No hay signos semejantes en la conducta de Maldonado. Recuérdense además las continuas vacilaciones de éste respecto a su salida. Hasta en los últimos tiempos, ya encausado, resolvió apelar a Roma, lo cual sugiere intención de quedarse en la Compañía. Por otra parte, la carta dimisoria del poeta Medrano es de enero de 1602, cuando los disturbios de Valladolid andaban en pañales, mientras que la de Maldonado, ahora conocida, es cuatro años posterior.

En la imagen de los ríos que se esconden y desaparecen, nuestro personaje parece aludir a su propia existencia: tenaz a la vez que indecisa, vigorosa por debajo de la inseguridad, capaz de vencer obstáculos como peñas. Por ello Medrano elogia el íntimo temple de su amigo cuando resuelve dedicarle la oda II. Dámaso Alonso ha señalado la estima que ese fino lírico sentía por Maldonado, a quien llamaba poéticamente Firmio. Cuanto más se conoce a Pedro mejor se aprecian ciertos versos:

Firmio, constante en las adversidades el pecho ofrece... ${ }^{\text {s9 }}$

Más adelante, observa Dámaso Alonso, el poeta vuelve a referirse a la entereza de su antiguo compañero:

Ya te embista el dolor, ya la alegría, atrás se vuelvan sin hacerte ofensa.

58 Cf. Dámaso Alonso, op. cit., I, pp. 38-40.

59 Ibid., pp. 43-46. Dice la nota 15: "La poesía estaba escrita probablemente mucho tiempo antes", y en un autógrafo "esta oda aparece dedicada a Luis Ferri"; luego, al estar "recién cambiado de orden Maldonado, vio Medrano, de pronto, que esta oda era muy a propósito como consolatoria para un hombre tan zarandeado". De alli que lo llame Firmio. Se ve que hubo modificaciones en la oda, pues se menciona el nombre y se alude al blasón de los Maldonado. 
A diferencia de Medrano, cuando éste abandonó la Compañía, Maldonado cumplió con la dimisoria y se mantuvo como religioso de observancia regular. La dedicatoria lo presenta ya como agustino, pues se dirige "A fray Pedro Maldonado". Tuvo por fuerza que ser de 1606, año en que Maldonado se hizo fraile y pasó por Sevilla; no más tarde porque en plena mocedad, meses después, moría Medrano.

Falta ahora saber si Pedro no hubiera tentado las musas. Alguna vez don Antonio Rodríguez Moñino habló de una escuela o grupo de poetas andaluces de la Compañía ${ }^{\mathrm{BO}}$. En el cancionero de jesuitas, manuscrito, que figura en la colección de aquel admirable erudito, hay composiciones de Medrano y también de un $P$. $M$. de quien sospechaba don Antonio pudiera ser Maldonado. Todavía nada permite confirmar esa conjetura, pero el uso de simples iniciales podría tener relación con los problemas en la orden.

¿Y el tratadillo político? Desde Nicolás Antonio consta que existieron unos Avisos al privado de nuestro autor, los cuales intento situar hacia diciembre de 1603 , cuando Maldonado era jesuita. ¿Por qué entonces las cuatro copias del Discurso o Tratado del perfecto privado se atribuyen todas al mismo, pero como fraile agustino? Una relectura da que pensar. En el texto se afirma, por ejemplo, que dos cosas destruyen a un valido: "vanidad y apetito de honra", "su sed de riquezas y su gula de honra"; "desenfrénase la honra y da en soberbia"61. Censura Maldonado la inútil esplendidez exterior, el nepotismo, la corrupción administrativa. Cualquiera diría que el socarrón autor anda enumerando los pecados del duque. Quien conozca las fantasías a que fue dado fray Pedro pensaría que se trata de una postrera barrabasada, no pudiendo con el genio e inventando una maliciosa venganza. Cabe que los Avisos aquellos que consigna Nicolás Antonio llegaran a Lerma. Hoy se ignora su paradero y bien valdría la pena cotejarlos con los textos de Madrid. Quizás tomó el privado aquellos moralísimos consejos como música celestial: nada sabemos. Quizás también fray Pedro, años más tarde, descubrió que su viejo opúsculo podía conseguir este segundo efecto. No hay base para afirmar que los enmendase y los hiciese circular, por lo cual hoy se llaman Discurso o bien Tratado del perfecto privado. Con tal personaje, todo pudo ocurrir: desde una superchería hasta obrar de buena fe; en

60 Construcción critica y realidad histórica en la poesía española de los siglos $x v i$ y xvii, Madrid, 1965, p. 56. Entre los grupos "nunca tomados en consideración", el gran erudito da como ejemplo "el jesuítico-andaluz, importantísimo".

61 Tratado, fol. 3llr (ms. 18335). 
sus enredos cortesanos más se perdió por dárselas de listo que por "doble como una cebolla". No hay modo, pues, de excluir, ni tampoco de afirmar que esas varias copias del Privado, abundantes quizás en un tiempo, obedezcan a una jugarreta de fray Pedro en sus últimos años. Si así fuera, esta vez no pisó en falso aquel pintoresco sevillano.

José DURAND

University of California, Berkeley. 